\title{
Non-Situated Learning and the Arts
}

\author{
Reesa Sorin \\ School of Education, James Cook University Cairns
}

It is the Christmas season in Cairns and the end of the school year. In art class, Grade $1 \& 2$ children are folding white square paper into eighths, then making careful cuts into the folds and around the edges. The end result - a snowflake to be displayed on the bulletin board. During music, children sing, "I'm dreaming of a White Christmas" and "Santa Claus is coming to Town." Sprayed-on snow decorates the mural with the large red sleigh in which sits Santa Claus, decked in long red pants, a red jacket with white fur trim, tall black boots, a toque and scarf.

Having grown up on the Canadian prairies, I am familiar with snow, the commercial marketing of Christmas from the day after Halloween (a celebration only just beginning to come into its own in Australia) until the last of the Boxing Day sales, and the plethora of songs that portray Christmas as snow-filled and overseen by a fat man in a red snowsuit who rides an old fashioned sleigh from the North Pole. While I am not Christian and do not celebrate Christmas, the White Christmas indoctrination followed me to school and through the community for most of my life. Christmas or not, snow is inevitable on the prairies.

I remember as well learning songs in music class about jumbucks, swagmen and billabongs and wondering what on earth I was singing about. I knew what a kangaroo was - evening on the freezing prairies you can see kangaroos in the local zoos. But jumbucks? Swagmen? Billabongs? And somehow they waltzed - waltzes were something you learned in after school dancing lessons.

\section{Situated vs Non-Situated Learning}

Learning in context, or situated learning, and beginning at the students' level, is a long-held educational belief, popularised by John Dewey (Egan, 2001a). Dewey and later Friere advocated for problem-based learning, using authentic situations that immediately affect the learners' world. The relevance of these situations, according to Friere, translated into academic engage by the learners (Queensland State Education, 2001). 
Situated learning is defined as "a theoretical perspective, the basis of claims about the relational character of knowledge and learning, about the negotiated character of meaning, and about the concerned nature of learning activity for the people involved" (Lave \& Wenger, 1991, p. 33).

Situatedness implies learning through apprentice-style partnerships with experts; often learning through observation rather than with formal teaching. It involves the learners in participating in different tasks with the support of the expert, and gradually introducing more complicated tasks (Lave \& Wenger, 1991). Hanks (in Lave \& Wenger, 1991) states: "a training program that consists of instructional settings separated from actual performance would tend to split the learner's ability to perform the skill” (p. 21). During this apprenticeship, learners may question the expert about various aspects of the task, as a means of constructing their knowledge. Gradually, support is withdrawn as the learner gains mastery and enters into the realm of the experts. Citing a tailor's apprentice as an example of situated learning, Lave \& Wenger (1991) describe the development of tailoring skills from the simple to the complex until the apprentice has developed expertise in all aspects of tailoring. While once struggling to sew a hem, the learner is now constructing entire suits independently.

But what if the new tailor, now living in the 21 st century, is confronted with a situation for which s/he is not trained. For example, a situation where environmental conditions have changed dramatically and fabrics and clothing styles must be adapted to the change? Having been trained in set ways of constructing garments, would the tailor have the skills to adapt to the new situation?

David Putnam (in Vatsikopoulos , 2000) makes a similar analogy:

If you time travelled, a very good doctor from the year 1900 to the year 2000, into an operating theatre, he literally would be an exercise in incompetence. He could take a cup of tea, take the patient's pulse and do nothing else at all, because basically, technology has obviated his original skills. You've taken a schoolteacher from 1900, put her in a classroom in the year 2000, gave her some chalk and a blackboard, she in most subjects could teach a class. Now that speaks unfortunately against the teaching process.

While situated learning allows learners to participate in the world as it currently exists and is presented by experts, it may be more limited in addressing change; as it affects us now and as 
it will affect the world of the future. According to Sorin \& Klein (2002), this is a world where individuals will experience multiple changes, requiring varied learning skills. "The set learning required in twentieth century schooling and career preparation is being replaced with broader based knowledges and skills that enable students to develop active citizenship within a social context" (p.1). Outcomes education crowds curricula with hundreds of contentspecific requirements that position learning as a marathon to be completed within a set period of time, often through sacrificing quality and depth of understanding.

Increasingly in Australia, schooling is moving to produce informed and active citizens who can use their creativity to solve problems and discover new ways of doing things. "Our society will require creative individuals able to communicate well, think originally and critically, adapt to change, work cooperatively, remain motivated when faced with difficult circumstances, who connect with both people and ideas and are capable of finding solutions to problems as they occur" (Department of Education, Science and Training, 2003, p. 5).

Rich Tasks, an educational initiative of the Queensland Government, is one of a number of initiatives that challenge this approach. Aiming to cut through diffuse curriculum, it focuses on building skills to address new and challenging life situations. Crossing disciplines and focusing on citizenship and lifelong learning, this approach aims for "developmental, cognitive and intellectual depth and breadth" as an approach to curriculum planning (Queensland State Education, p. 5). And what better way to develop this depth and breadth than through the imagination?

Egan (2001a) questions a situated approach to learning, challenging educators to begin not with what the familiarities of what learners already know, but with what learners can imagine. Describing imagination as "the core of children's thinking" (Egan, 2001a, p. 1), Egan states: "we need not become constrained by trying to make content associations with knowledge students already have - there are other ways of expanding knowledge" (p.4).

"Schools and teachers need to cultivate in students - and themselves model - creativity, imagination, original thinking, open-mindedness and critical thinking" (Department of Education, Science and Training, 2003, p. 7). Imagination serves as a bridge to the unknown. With reference to the talking rabbits of Beatrix Potter or the wizards in Harry Potter and Lord of the Rings , Egan (2001a) notes that between binaries such as reality and fantasy, imagination "allow(s) much freedom in how they [learners] can go about grasping the 
universe of knowledge." It is through development of the imagination that learners mediate their world, making sense of the unknown through images, words and metaphors.

Imaginative skills, along with other intellectual capacities, see their strongest development in the early childhood years, gradually declining as we move towards adulthood. But a welloiled imagination helps learners "to keep us intellectually flexible, creative, and energetic in modern societies" (Egan, 2001b, p.2). Non-situating learning exercises imaginative skills as it takes learners out of their comfort zone and into areas that challenge their understandings. Scenarios such as the snow-filled Christmas scene in tropical Australia or jumbucks and billabongs on the Canadian prairies can be consciously introduced as gateways to explore imagination and deep understanding.

Non-situated learning, as the term is used in this paper, does not assume that the teacher is the expert who doles out knowledge to students. Framed by the Reggio Emilia approach to teaching (Edwards, Gandini \& Forman, 1993), and the construction of the child as agentic (Sorin \& Galloway, 2005), the teacher in non-situated learning acts as a guide and co-learner, helping students to identify and follow learning interests and to find resources with which they can engage to develop their understanding.

Unlike Reggio Emilia, where learning is presented in a home-like environment, with plants, decoration and furniture reminiscent of children's own homes, this approach to learning welcomes unfamiliar environments, where learners' imaginations are required to mediate understanding and explore issues. Learning is not a process of scaffolding what the learner already knows, but a process in which new and unexplored possibilities are introduced (Egan, 2001b). Spencer (1969 in Egan, 2001b) states: "Children should be led to make their own investigations, and draw their own inferences. They should be told as little as possible, and induced to discover as much as possible" (p.2).

\section{Non-Situated Learning and the Arts}

The arts, partnered with language processes such as storytelling, metaphor-building and poetry writing, assist learning and imaginative processes; from remembering or rote learning through to understanding and applying information to new situations, recognising patterns and relationships, creating new information and evaluating existing knowledge. Egan (2001b) states: "We remember things best when we can locate them emotionally and associate them 
with some vivid image...which helps to account for the greater richness we typically experience from generating our own images from text or listening to an oral story than from seeing images presented to us on film or television" (p.4).

The arts help children to develop their intuitive, creative and imaginative abilities. These in turn lead to reflection and deep understanding of the world around them (Queensland School Curriculum Council, 2001) and of worlds far away (Egan, 2001b).

Learning through the Arts, a Toronto-based program that partners teachers with practicing artists in planning and teaching core curriculum through the arts, is an example of how the arts can be used to develop students' imaginations and understanding. In the Science study of "energy", students would be asked to find three shapes that demonstrate potential energy, to create movements for these shapes, and to combine movements to create a dance about potential energy (Houser \& Fisher-Lang, 2003).

Teachers can help students to investigate topics through music; communicate through dance or drama; design new, never-before-seen worlds through visual arts; and create new beings through media. A non-situated learning approach utilising the arts (drama, puppet making, face painting and painting) was trialled in a Grade 1 class in Cairns, Australia to examine some of these ideas. There were twenty children in the class, and a few of them had a minimal idea about the topic, but all had experienced various literacy activities that required them to think creatively and make choices.

\section{Sambo and the Pine Needle Stew}

Skunks are as unfamiliar to Australians as sea snakes, bilbys or numbats must be to Canadians. So the unillustrated story, Sambo and the Pine Needle Stew (Swan, 2005) seemed like a good starting point. In the story, Swan reminisces about his childhood vacations on the shores of Lake Ontario, where at one point Sambo, his cocker spaniel, encountered a skunk beneath the family cottage. Unfortunately for Sambo, she came off second best in the encounter, which resulted in both her and the entire cottage smelling of skunk. A friendly neighbour saved the day, bathing Sambo in tomato juice and cooking pine needles in a pot on the wood stove to quell the odour indoors.

I began by introducing the story, noting that it was about a dog and a skunk, and that it had no pictures. When I asked the children what they knew about skunks, a few mentioned that 
skunks are black and white. I asked them to listen to the story and, if they wanted, to close their eyes and imagine what the story might look like. I read through the story with very few stops then, re-read it stopping at key points to explore ideas through the arts.

At a point where the dog came face to face with the skunk, I asked the children to imagine what it would be like when Sambo saw "2 BIG WHITE EYES" (Swan, 2005) looking at her. How would her face look? How would her body look? The children's eyes widened and faces contorted, as they assumed defensive, animal-like postures. The story noted that Sambo had never seen a skunk before. At this point, I helped the children to form a circle and began a "Rumour Mill" (O'Toole \& Dunn, 2002), where they were asked to think back about how they had imagined the skunk to look, and to give one piece of information to the person on their left and another piece of information to the person on their right. This meant that they not only had their own ideas, but ideas from two other children. As a group we shared some of these ideas, including that skunks were furry, had big tails and smelled bad. I then suggested that they might like to get more information about skunks and asked them who could give them more information. From their suggestions), we decided to ask a park ranger.

I told them that I would be the park ranger, and put on my "ranger hat". A drama "hot seat" activity followed where, as ranger I asked for their help in locating the skunk and they asked me for further information about skunks. The children shared their knowledge (from imagining the skunk and from the Rumour Mill activity) and we worked out that skunks are about the size of cats, but with different shaped heads and glands that secrete an odour. We discussed what they eat, where they live and how much of a danger they were to people. This activity seemed to provide them with a clearer understanding of skunks. The classroom teacher commented: "The Ranger act was very effective and the children took your changed roles in stride...the way you wove a story into this by 'looking for the skunk' was powerful when questions were not forthcoming'." I then removed my Ranger hat and resumed the role of "narrator".

In the story, when Sambo encounters the skunk, the family hears "A LOT OF NOISE under the floor" (Swan, 2005). We discussed why this would be and what kinds of noises they might have heard, and I produced a number of items with which the children could make sounds, including, leaves, shredded paper, twigs and percussion instruments. I invited small groups of children to come up and make the kinds of noises that might have been heard under the floor. The sounds each group made were carefully produced to match what children had 
imagined, rather than a loud, raucous free-for-all. During this time, one child remarked that Sambo also would have made a sound, and proceeded to yelp like a dog. Another said that a skunk might thump and hiss, and used a wooden instrument to make a thumping sound, while making hissing sounds with his voice. With these two children leading, I asked the whole group to make a noise together, and they produced a soundscape of the noises under the floor. This followed with moving like Sambo might have moved when running from the skunk, then like the skunk might have moved. As dogs, their bodies moved rapidly, rolling and running to avoid the skunk. But as skunks their backs curved, claws came out and they moved slowly and stealthily like predators.

When we reached the part in the story where the dog was bathed in tomato juice (to remove the skunk odour), I asked the children to pretend they were getting tomato juice shampoos. They rubbed their heads and a number of them made faces as they contemplated tomato juice in their hair. The story concluded with the neighbour making a pine needle stew (to replace the skunk odour with nicer scents), which we discussed in great detail, linking pine needles to Christmas trees and colder countries and stew to something you would cook to eat. We talked about other things that could go into a pine needle stew, if you lived in a place where there were no pine trees but you wanted interesting smells. They suggested leavers and flowers.

Three activities followed this second reading of the story. Some children went to collect items to make a pine needle stew (leaves, bark, branches and flowers cooked in a large pot and then cooled); others used face paints to paint themselves to look like skunks; and still others made skunk puppets from the variety of materials provided, including old CDs, Paddlepop sticks, paper, yarn, ribbon, etc.

I had planned to do further activities with the class (painting and collage), but due to time had to limit it to the three activities described above. But before leaving the class, I gave the children two pieces of information: the web address of an informative skunk site and the email address of Billy, the young boy in the story (actually the story's author, who had agreed to answer any questions or comments from the children). I gave them no further information, and the children went to eat their lunches.

The classroom teacher describes what happened after I left the class: 
The [pine needle stew] 'stewed' over the lunch break and through middle session. Just before afternoon tea at 1:20 we saw, smelled and commented on the [school] stew. By then the stew had become a murky brown colour but the ingredients were still clearly visible - bark, leaves, flowers and sticks. Although many children did not like the smell, they described it as reminding them of 'tea, leaves, flowers, baked beans and bark.' For me, the stew smelled like leaves and bark and it was certainly reminiscent of 'tea'.

During the lunch break, a few children who had painted their faces went to the school canteen to purchase their lunches. They reported:

The [canteen] ladies thought we were real skunks and one lady said, "Oh, that's that awful smell."

A [canteen] lady said, "Look, there's a skunk. It might spray you."

H (showing her claws and snarling “Aaaaah !”) said, "The lady was scared of me.”

When they teacher asked the children what they'd learned about skunks from the morning's activities (and before further research was carried out), their replies included:

L: ... that they can spray far.

$\mathrm{T}:$... they can live in logs.

$\mathrm{F}:$... that they have two glands that they spray from.

J.D: ... and that the glands are near and under the tail.

M.C: I learned everything about skunks because I didn't know about skunks before.

J.B: ...that skunks live in Canada and they live in cold weather.

$\mathrm{J}:$... they are black and white.

The teacher then inquired about what they liked about the story and the morning's activities. Responses included:

M: The stew. It smells nice... and the story. 
E.D: making the puppets.

$\mathrm{T}:$... that the ladies at the [canteen] thought we were skunks and we pretended to be skunks.

Sh : When Reesa dressed up as a Ranger. She was scared because she couldn't find the skunk.

$\mathrm{J}:$ Getting the stuff for the stew.

$\mathrm{H}$ : Listening to the story

Ch: In the yard people asked about the face-painting

Mi: Face-painting

J.C: The story... when the dog got scared in the story .

Jo: Making the skunks

$\mathrm{K}:$ The story... when the man put the tomato juice on the dog.

The teacher followed up my activities with a painting activity, where a number of children represented their images of skunks on paper, and a group writing activity where the children wrote to Billy from the story. A few days later, one of the children brought a skunk mask to school that she had made at home with her mother. I printed some of the photos that were taken during my visit and sent them to the class, asking if they could write about the pictures.

The teacher suggested further follow-ups, including: illustrating the story, page by page, making a puppet show with their puppets, researching further information on skunks through the website and books, and writing their own stories from drawings, paintings, and photos taken of the event. In this way, fact and fantasy can combine not only to reach deeper levels of understanding, but also to help develop learning and imagination skills necessary to our ever-changing world.

\section{Scenarios Revisited}

Using a non-situated approach to learning could re-focus the scenarios presented at the beginning of this paper so that rather than presenting unfamiliar information in ways that tend 
to limit understanding, they could become opportunities for imaginative learning and developing deeper understanding. Children in Australia could be asked to imagine a cold, white, snow-filled Christmas. They could be encouraged to explore snowflake shapes through movement, could make the sounds of falling snow with musical instruments or could dramatise the reindeer moving the sleigh across the world. They could create their own Australian version of Santa - one that would better suit the warmer lifestyle. In turn, Canadian children could imagine a very hot Christmas, where Santa would need a wardrobe re-vamp and may have to substitute reindeer for wallabies and a sleigh for a surfboard. The cold and snow could be replaced by sunshine and droplets of sparkling, misty rain.

In non-situated learning, the jumbucks of my school days could be jumping horse-like animals and waltzing could be animals of many colours and unknown species dancing in fields with swaying, not quite human people. Through dance, drama, art and music, these and other ideas could be explored and facts, introduced as a supplement to this exploration, could then be further developed through the arts.

\section{Conclusion}

While situated learning, or learning in context, has long been recognised as an effective way of passing on knowledge and skills from experts to novices, it may be less successful in developing the imaginative and creative skills necessary to deal with change as it is occurring in the 21 st century. Non-situated learning, or taking learning out of context and exploring concepts through the arts, is a way of not only exercising the imagination but of helping to develop deep and rich understanding. This is particularly the case when utilising the arts as a medium for this exploration. Learning becomes not only fun and experimental, but incorporates the visual, auditory and kinaesthetic in ways that can suit every learner and content area.

\section{Bibliography}

Department of Education, Science and Training. (2003). Australia's Teachers: Australia's Future - Advancing innovation, Science, Technology and Mathematics. Canberra: Commonwealth of Australia. 
Edwards, C., Gandini , L. and Forman, G. ( eds ). (1993). The Hundred Languages of Children: the Reggio Emilia Approach to Early Childhood Education. Norwood, N.J : Ablex Publishing.

Egan, K. (2001a). Start with what the student knows or with what the student can imagine? AERA Conference presentation. Online at http://www.educ.sfu.ca/kegan/AERA $\underline{\text { Startimagine.html }}$

Egan, K. (2001b). The arts as "the basics" of education . Online at http://www.educ.sfu.ca/kegan/AERA -Startimagine.html

Houser, T. and Fisher-Lang, A. (2003). Learning through the Arts: Enhancing teaching and learning. Imaginative Education Research Group International Conference proceedings. Available at: http://www.ierg.net/pub conf2003.html

Imaginative Education Research Group. (2004). A Guide to Imaginative Education. Burnaby, British Columbia: Imaginative Education Research Group.

Lave, J. and Wenger, E. (1991). Situated learning - legitimate peripheral participation. Melbourne: Cambridge University Press.

O'Toole, J. and Dunn, J. (2002). Pretending to learn - helping children learn through drama. Frenchs Forest: Pearson.

Queensland School Curriculum Council. (2001). The Arts Syllabus. Available online at http://www.qsa.qld.edu.au/kla/arts/syllabus

Queensland State Education. (2001). New Basics - the why, what, how and when of Rich Tasks. Brisbane: Queensland Government.

Sorin, R. and Galloway, G. (2005). Constructions of Childhood: Constructions of Self. Childhood 2005 International Conference presentation. Oslo, Norway.

Sorin, R. and Klein, M. (2002). Walking the walk and talking the talk - adequate teacher preparation in these uncertain times? Australian Association for Research in Education Conference Proceedings. http://www.aare.edu.au/02pap/sor02045.htm 
etropic 5 (2006): Sorin, Non-Situated Learning and the Arts

Swan, W. (2005). Sambo and the Pine Needle Stew. Unpublished monograph.

Vatsikopoulos , H. (producer). (2000). Thinking Ahead. Australian Broadcasting Corporation Lateline . http://www.abc.net.au/lateline/arachives/s116742.htm 